\title{
The Political Rhetoric of Capitals: Rome and Versailles in the Baroque Period, or the "Power of Place"
}

\author{
Peter Rietbergen
}

\section{Introduction}

Surely, amongst the world's capitals Rome is the one most captured in paintings, photographs, and films but, also, most subjected to scholarly scrutiny. ${ }^{1}$ On the other hand, amongst the world's royal palaces Versailles undoubtedly is the one most pictured as well as researched. ${ }^{2}$ Yet, people tend to forget that Versailles was more than a palace: it was also a city, and even, from the 1680 s to the 179os, the "de facto" capital of France, whereas the city of Rome, from the early sixteenth century onwards, became the greatly enlarged extension of that one, unique building complex, St Peter's basilica and the adjoining Vatican, or Apostolic Palace.

This contribution takes up the volume's theme of representation of power and public display by analysing and comparing both palace-cum-cities as rhetorical texts that aimed to proclaim a message of supreme power. I will concentrate on what historians customarily term "the early modern period" - which, when art-historians study it, coincides with both the Renaissance and the Baroque. My particular focus will only be on the Baroque. In doing so, my analysis of what one also might call the "semiotics" of these towns-cum-palaces will reveal both similarities and differences. This contribution will furthermore demonstrate how physical expressions of power can be seen as a prime instrument of legitimising power. I hope to contribute to the growing corpus of research that addresses the political rhetoric of the built environment in general and of the urban landscape in particular - "the power of place."

Obviously, the innate tendency of power to represent itself in as many ways as possible - including through the art of propaganda, which is the more

1 Cf. Rietbergen (2003).

2 For the complex role(s) of Versailles, see the historiographical, introductory chapter of: Sabatier (1999). However, amongst more recent studies Duindam (2003), is, easily, the most comprehensive and authoritative. 
"active" form of representation -has always led rulers to try to structure the "loci" of their power in ways they felt to be "orderly," preferably referring to a hierarchical, authoritative and, indeed, often authoritarian order.

In many cultures, this desire has expressed itself in palaces and cities that mirrored the perceived order of the cosmos, an order, moreover, that often was seen as balanced and symmetrical. ${ }^{3}$ This is not surprising for, as some psychologists such as Carl Jung (1875-1961) have argued, symmetry gives our mind a sense of primordial harmony and security as much as, or perhaps precisely because it also structures the physical universe. ${ }^{4}$ Mircea Eliade (1907-1986), one of the founding fathers of comparative mythology, has stressed the importance of visual and, therefore, ceremonial and ritual "centrality" in many of the world's cultures as well. ${ }^{5}$

All over the world, this archetypal form of conceptualising space was also reflected in town-founding and town-planning, usually accompanied by geomantic rituals and, thus, resulting in a kind of cultural astronomy. In the Hinduist as well as in the Buddhist-Confucian "oikoumenai," this desire for order and hence control has resulted in the construction of imperial cities modelled on the "mandala," an "essence-container," a microcosmic "model" of the universe combining the square and the circle. ${ }^{6}$ In Judaeo-Christian culture, the fundamental book of the Jews, the Old Testament, presents heaven as a place and, moreover, a temple, a tabernacle, a throne room. In the New Testament of the Christians, especially in the Book of Revelations, heaven is detailed as a world consisting of concentric circles, the innermost of which is a - or rather "the" - city, the "heavenly Jerusalem," the "City of God." Yet, the city itself is described as a square with, on each of its four sides, three gates. In it, God's throne-room is located. ${ }^{7}$ Not surprisingly, medieval and Renaissance representations of Jerusalem and, consequently, Rome, often tended towards the circu$l_{a r}^{8}$ - as, for example, shown in the thirteenth-century so-called "Ebstorf-map," or the view of Rome in the fifteenth-century manuscript Les tres riches Heures du Duc de Berry and others ${ }^{9}$ - though the actual topographies of these towns were anything but mandalaic.

3 For a very short survey: Patricios (1973); Bird (1977/2007). Concentrating mainly on recent developments, but offering a good general introduction: Minkenberg (2014).

4 Zabriskie (1995).

$5 \quad$ Eliade (1961) 20-40.

6 Cf., for example, Smith (1987); Narayan (2015), who also refers to classical Indian texts concerning city-building, and: Ten Grotenhuis, (1999), who deals with China as well. Last, but not least: Zhu (2004).

7 For a survey of various concepts of heaven: McDannell (2001).

8 A few examples are shown on: $<$ http://mappingrome.com/medieval-rome/>.

$9 \quad$ Other examples are Taddeo di Bartolo's map in a fresco in the townhall of Sienna (ca. 1415), the maps adorning Ptolemy's Cosmography of the late 146os, Alessandro Strozzi's 
While many rulers did not hesitate to build palaces according to variants of these and other orderly visions, few actually succeeded in also creating an entire (capital) city "ex novo" - not only because financial and other practical considerations precluded such grandiose experiments, but also because existing capitals often were considered sacred, hallowed by the dynastic and imperial traditions that were part of the sovereign's heritage and, thus, of his (claims to) power. Abandoning them was, therefore, not advisable.

Still, in 1346 вс Pharaoh Amenophis IV, better known as Akhn-Aton, did decide to leave ancient Thebes with the unruly priest-caste he hated and created his new capital at Akhet-Aton (The Foundation of the Sun). In $836 \mathrm{AD}$, the Abbasid caliphs moved from Bagdad to Samarra. Likewise, in the early fifteenth century, the Yongle Emperor left Nanjing, and made Beijing the imperial city, constructed according to rigid geomantic-cosmological principles. And in India, in 1569, Emperor Akbar replaced Delhi with Fatehpur, the "city of victory." Last but not least, from 1598 onwards Shah Abbas, the ruler of Safavid Iran, created a new residence at Isfahan.

Yet, most monarchs had to satisfy themselves with imposing their visions of power on existing cities. In a sense, Rome and Versailles represent these two "types": the one an old capital constantly adapted to new visions of power, the other a new capital specifically devised to do so.

\section{The "City Eternal"}

To both secular and religious leaders the city of Rome, throughout its long history, offered unique possibilities for the representation of power. However, when the popes returned to Rome after their exile in Avignon, the city was not a sight that pleased them. While they were proud monarchs wanting to compete with and hold their own against the so-called new, absolute monarchies now slowly evolving in the European political landscape, the outlook of the city and the ordered and ordering view of the new, Humanist-Renaissance ideals of symmetry and classical balance did not quite fit their purposes. ${ }^{10}$

Nevertheless, their return had been ineluctable: the "mana" of the papacy originated in, and, indeed, remained insolubly tied to, the sacrality conferred

map of 1475, and Sebastian Münster's representation in his Cosmographia, of 1544. Even the far more accurate map in the famous Braun-Hohenberg-atlas of 1585 still suggests a circular city. Cf. however also: Müller (1961). own, earlier work on papal Rome, specifically: Rietbergen (1983a) chapters II and VII; Rietbergen (2006) chapter IV; Rietbergen (2013); Rietbergen (2015) chapter I. 
on it by the tomb of St Peter's. The very foundation of papal power was, after all, their claim to primacy amongst the Church's many bishops, as the successors of the first among the apostles, who allegedly had been named his vicar by Christ himself, and whose very relics were embedded in the foundations of the basilica built atop his tomb. With its additional hundreds, or even thousands of graves of martyrs and saints, Rome was a sacred city, the capital of Christendom as well as Christianity.

In short, though during their years in Avignon (1309-1377) the Curia had succeeded in building both a formidable - as we now would say: proto-modern bureaucracy and, as an important part of it, a fiscal system that gave the papacy enormous power, the popes could not afford to permanently leave the town of their origin. Without Rome, the pretences of the papacy were baseless. Consequently, precisely to preserve and even strengthen their position, they felt forced to return to it. But the Rome they found was not an "ideal," cosmically-oriented town. It was a "medieval" town, i.e., a town that had grown haphazardly, without any order, having evolved around the fortified residences of the warring urban aristocrats, who for centuries had competed with the popes. A town, also, strangely dominated by huge, half-ruinous monuments referring to an obviously great past that, however, only was dimly understood.

Still, before the popes could turn their attention to the town at large, a critical look at their ideological mainstay, the basilica of St Peter's, was necessary. It taught them that, after a millennium, the great church first built by the Emperor Constantine - to the terms of whose so-called donation the Curia still referred when defending the papacy's secular, princely power over Rome and central Italy - could no longer serve as the worthy reliquary of the Apostle's remains and hence as the church wherein they, his rightful and, indeed, only successors, would celebrate their power: not as bishops of Rome but as rulers of the entire, "universal" Church.

Therefore, already Nicholas V (1397-1447-1455) decided not to restore St Peter's to its ancient outlook but to replace it with a new, far greater church that would show the splendour of the imperial tradition in which it had been first conceived, a splendour that his advisers and architects now felt they could recapture because their Humanist learning allowed them to better understand those ancient times. While the plans of Nicholas did not mature, one of his successors, the great warrior-pope Julius II (1443-1503-1513), who managed to create what soon became the "state of the papacy," resumed his ideas.

Hence, in 1506, a start was made with the immense building that, more than a century later, became St Peter's as we now know it. Not surprisingly, the horoscope cast for laying the building's foundation stone - a typical Humanist practise - was constructed in such a way that the stellar constellation most 
propitious to it had been modelled on the one that reputedly held for Jesus of Nazareth himself. And, of course, the birthday of Christ traditionally had been linked to the day of the creation of the world. ${ }^{11}$ Thus, the basilica became the nexus of Christian time and space, the navel of God's cosmos. Its Greek-cross ground-plan followed what were understood to be the basic elements of a representation of cosmic hierarchy and order: its perfect square was crowned by the perfect circle, Michelangelo's great cupola.

By the turn of the century, with the cupola complete, the then architect-inchief, Carlo Maderno, proposed to surround the basilica with a series of lower chapels, each with its own cupola. If this design, which harkened back both to Michelangelo's and to the earliest plan for new St Peter's by Bramante, had been executed, the world would have seen the greatest mandalaic church ever, resembling both the third Hagia Sophia at Istanbul and, the epitome of such sanctuaries, the Borobudur on Java - both representations in stone of the "holy mountain" common to so many mythologies.

However, in 1607, it was decided that the old, Renaissance-Humanist plan of St Peter's was a "pagan" symbol. Yet, the new plan - based on a so-called Latin cross with, consequently, a proper nave - did not basically alter the basilica's function. Though both the Vatican and the Lateran palace had throne rooms, as did the papal summer palace on the Quirinal Hill, St Peter's is the real papal throne room - as well as, always, the most public one. Over the course of its long construction, the church went through a number of design stages. Still, all the architects involved - Michelangelo foremost amongst them - felt they were creating a truly imperial symbol, worthy of the man who combined the power of Christ's vicar with that of a secular prince ranking first amongst the monarchs of Christendom. There, the pope verily shows (the origin of) his unique power. For he celebrates under the huge, bronze canopy erected by Bernini in the 1630s, exactly above the tomb of the Prince of the Apostles. And behind him, all those present in the basilica - it can seat some 20,000 faithful, or, alternatively, accommodate some 6o,ooo people standing - see the "Chair of St Peter," encased in bronze in the apse. As an essential part of this symbolical-referential monument, a dove hovers over it in the stained-glass of the window whose light floods it all: the Holy Spirit is always with the papacy. In other words, this was the prime location for the pope to legitimise his power as well as the most appropriate place for the faithful to express their loyalty to God and to the pope.

Even if a Roman pontiff ever had considered creating a new capital for the Church he presented as universal, and, moreover, if he ever had had the means 
to do so, he would always have been reminded of the basic fact already referred to above: without Rome, no papacy. If the popes wanted a capital that reflected their political, ideological, and religious beliefs - a town that, in short, resembled the ideal "Civitas Dei" - it had to be constructed within the materiality of contemporary Rome. To realise this vision, to make Rome into a "new Jerusalem" that would impress both the masses of pilgrims who annually arrived there - an important source of income, too - and the embassies of the Christian princes who sought out the popes both as temporal rulers of Central Italy and as arbiters of Christendom and, increasingly, as leaders of a truly global organisation, massive changes in the urban structure would have to be made.

Obviously, Rome once had been the capital of the greatest empire Western Eurasia had ever known. Indeed, from the fifteenth century onwards, precisely the representational significance as well as possibilities of the Caesarian ruins dawned upon the town's politico-cultural elite. Ideologically, this resulted in a vision of Rome that somehow gathered the remains of the "pagan," imperial city and the buildings created in more recent, Christian-papal times into one convincing synthesis. ${ }^{12}$ In terms of city-planning, this vision was realised through a series of grandiose projects that were as practical as they were propagandistic.

Obviously, these schemes always involved St Peter's. However, the Vatican Hill, on which both the basilica and the adjacent palace had been built, lay outside the "original" Rome, the Rome of the imperial age and the "Middle Ages." The two needed to be linked, not only because the town proper held so many other significant Christian sites and monuments, not only because there the church-and-palace of the popes as bishops of Rome was situated in the Lateran quarter, but also because, since times immemorial, all roads which proverbially led to Rome literally converged upon the old centre.

Therefore, Pope Nicholas decided to integrate the Vatican quarter into Rome by no less than three new, rectilinear, porticoed thoroughfares which proudly would cut through the jumbled mass of medieval houses and other buildings covering the hill..$^{13}$ These constructions, he felt, would powerfully proclaim modern architecture, which, according to his advisers, now took on the reborn, classicist forms of the old empire. Although the original design was not executed, a few decades later a watered-down form was. Thus, today, streets in front of the basilica slope down to the banks of the Tiber, where an old bridge connects them to the city's main body and the roads that reach Rome from the North.

12 Rietbergen (2003) part I.

13 Westfall (1974). 
Around the turn of the century, Julius II ordered the construction of the "Via della Lungara" and the "Via Giulia," two even longer streets which, running parallel to the banks of the river, linked the seat of papal power to Rome's venerable ancient centre: the Capitol. Given the propagandistic need of these projects, as had happened around the Vatican, people who owned property that stood in the way were either bought out or, sometimes, ruthlessly expropriated.

Three other pope-kings must be credited with the creation of papal Rome as we now know and see it. The first is Paul III (1468-1534-1549). Following ideas and constructions already started in the early decades of the sixteenth century, during his reign a piazza was laid out just inside the "Porta del Popolo," the ancient Roman gate which opened onto the Via Flaminia that led from Rome to Milan and on towards the Alps and Northern Europe from where most pilgrims came. From the piazza, like the prongs of a trident, three long, straight streets were "bored" into the corpus of the city: the left-hand one along the slope of the Pincio Hill to the bottom of the Trinità de' Monti, and the middle one, the Via del Corso - following the old "Via Lata" - going up to the Capitol. There, where the ancient Roman Republic had had its seat, Michelangelo now realised a new city centre, expressing the domination of papal authority over the once-independent communal leaders. The third and last of the three streets led from Piazza del Popolo to a point on the bank of the Tiber where one could see, on the other side, the majestic, though at that time still unfinished mass of new St. Peter's rising like a mountain on the city's horizon. ${ }^{14}$ Together, these new thoroughfares should demonstrate the "Renovatio Urbis," the revival of Rome's imperial splendour. ${ }^{15}$

The second pope to address the ideological impact of Rome in its entirety was Sixtus V (1521-1585-1590, see Figure 5.1). ${ }^{16}$ First, he finalised the building of the huge cupola of St. Peter's that dominates as well as characterises Rome's skyline even today, but whose construction, according to the design of Michelangelo, had lain dormant for decades. During the five short years of his pontificate, Sixtus also ordered the lay-out of a few more very long rectilinear streets that connected the city centre as defined in the previous pontificates to, specifically, the far-away but ceremonially-liturgically important basilicas of Santa Maria Maggiore, St John Lateran, and Santa Croce in Gerusalemme. Moreover, at all important intersections of these streets, as well as of the ones

14 Ciucci (1974). Also: Ackermann (1982); Frommel (1986) did not add much to either my own or other earlier contributions.

15 Cf. Delph (2006).

16 The literature about Sixtus's urban planning is extensive. See for a historiographical survey: Sinisi (2010) xxx, note 37 . 


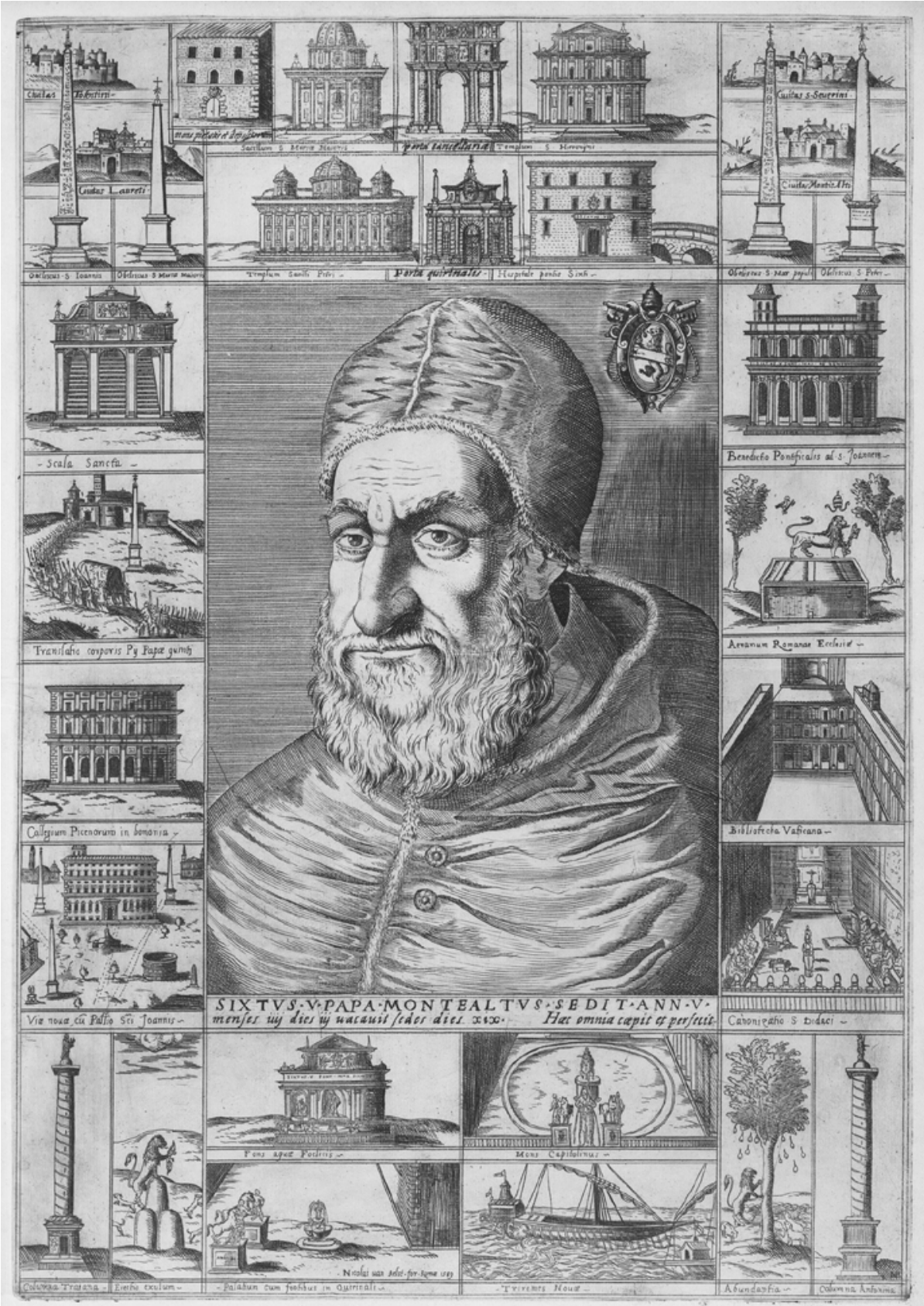

FIgURE 5.1 Portrait of Pope Sixtus v (r. 1575-1580). Published by Nicolaus van Aelst (Flemish, Brussels 1526-1613 Rome). Credits: The Elisha Whittelsey Collection, The Elisha Whittelsey Fund, 1949 (CCo 1.o) [accessed online 28.02.2019, <https://www. metmuseum.org/art/collection/search/369588>]. 
constructed during the preceding century, he had obelisks set up, the most magnificent one in front of the new St Peter's. Also, at strategic places monumental fountains were built. Thus, Sixtus completed the grid of streets created between the late fifteenth and the late sixteenth century. The result was an urban "net" in which the visitors of the Eternal City were captured - an effort at "spatial Christianisation," one might say, in which they were directed from one splendid sight to another, always ending up in front of one of the city's seven main churches. Visually, too, Rome had become a sacred city, the sacred city.

Indeed, even those who never were fortunate enough to visit Rome now could experience it, for from the sixteenth century onwards, both small and large printed maps - like the one produced by Antonio Tempesta in the 1590s, which shows some of Sixtus's streets - and engraved plates publicised Rome, enabling the wider world to see that the Eternal City was the most wondrous town of their world. ${ }^{17}$ These publications were definitely intended to serve as printed propaganda for the urbanistic schemes of the papacy. Moreover, they formed a welcome for additional and pictorially attractive sources of information besides the traditional guidebooks usually presented under the caption "Mirabilia Urbis Romae," which included both short texts that gave pilgrims and other visitors a survey of the "Indulgentiae Ecclesiarum Urbis Romae," and the longer ones that (also) provided a "Historia et Descriptio Urbis Romae."18 To address as large an audience as possible - i.e., both the actual pilgrims and other visitors, and the "armchair travellers" - these guides were published in a variety of languages. They were frequently updated to show the on-going changes in the townscape.

The third pope to leave his indelible imprint on Rome's cityscape and, indeed, to make it an enduring image of the papacy, was Alexander VII (15991655-1667). He tackled the problem of the very undignified sandy space stretching out in front of the grand basilica that had pained his predecessors for almost 150 years. From $165^{6}$ onwards, the design genius of his architect Gianlorenzo Bernini - and the manpower of several hundred artisans and other labourers - created a unique piazza: its form linked two circles into a grand oval. ${ }^{19}$

Meant as an open-air "theatre" - the very term was used at the time - for the church and, indeed, the Church, the piazza was defined and embraced by the

\footnotetext{
17 See, also, San Juan (2001).

18 Fundamental for our understanding of this complex "genre": Miedema (1996); Miedema (2003).

19 Cf. Kitao (1974).
} 
curves of two huge travertine colonnades. Their 284 columns carry an entablature crowned with the marble statues of 88 saints $^{20}$; thus, heaven is represented on earth, with the "arms" of the colonnades, reaching out as if to receive the faithful in the fold of the "Ecclesia Romana": the only way to eternal salvation. At the piazza's heart stands the obelisk transferred there already in 1586 by Sixtus v. It serves as a gnomon, indicating the hours of the liturgy, while the open span between the arms of the colonnades themselves covers the moments of daily sunrise throughout the course of the year. Thus, the piazza seems to represent the cosmos as well. Looking up at the cross atop the obelisk and beyond it, towards the cupola of St Peter's, those who enter this space truly experience the totality of papal power that had succeeded in making Rome God's "city on earth". 21

Of course, descriptions of this spectacular piece of architecture and urban planning immediately were incorporated in the guidebooks, as well as shown on the maps of Rome. Indeed, because the popes wanted propagandistically to use this, their last great architectural exploit, many artists - painters but also draughtsmen and engravers - now concentrated on views of Piazza San Pietro, depicting it in all its undeniable grandeur. It had become the apogee of the rhetoric of papal Rome.

\section{The "City of the Sun"}

While the popes in Rome searched for physical expressions of their power through St Peter's and through the city of Rome itself, in France we witness a different attempt of representation of power in the palace-cum-town that truly became the centre of a cult if not devoted to the Sun then, certainly, to the Sun King. Why Louis XIV, at the age of 23, started building and continued rebuilding his main residence in the old village of Versailles and, moreover, in 1682 transferred the entire business of government to it as well, thus for all practical and indeed also ceremonial purposes leaving Paris, is a question much discussed.22 Admittedly, Louis's childhood memories of Paris had caused a trauma. As a young boy, he had felt the revolt, both of the French nobles and

20 The total is far higher if one also counts the statues crowning the buildings bordering the trapezoidal "square" in front of the basilica.

$21 \quad$ Rietbergen (1983b) 11-163, 237-41.

22 From the huge literature about Versailles, I cite: de Vinha (2009) and Torres (2015), not because they are the most scholarly but because they do present the history of the palace in some readable grand lines. For specifics: Bluche (1999); Berger (1985); Perouse de Montclos (1991). 
of the Parisian population, against the rule of the queen-regent, his mother, and of her all-powerful adviser, Cardinal Mazarin, as a personal insult, an attack on the power and authority that by birth were rightly his, God-given to the kings of France. So, the choice to leave the Louvre, and even take up residence outside the ancient capital was, perhaps, not incomprehensible.

Moreover, certainly after the famous festivities staged in 1661 by the powerful director-general of France's finances, Nicolas Fouquet, at his newly-built palace of Vaux-le-Vicomte, not only Louis's jealousy was aroused - the "fête" speeded up Fouquet's downfall - he also very much became aware of the methods and means that would allow him to "fabricate" his own image and, hence, his kingship. ${ }^{23} \mathrm{~A}$ new, modern palace adorned with everything the Arts could contribute would be the perfect vehicle for royal propaganda. Yet, the choice of Versailles remains enigmatic. Again admittedly, between 1632 and 1634, Louis's father, having bought the manor of Versailles which included a small village of that name, had built a hunting lodge there, of red brick and sandstone. ${ }^{24}$ Still, piety can hardly have been his son's main motive to settle there, given that the site was insalubrious and certainly not spectacularly beautiful.

Last but not least, the suggestion that the little hill-and-vale where the village and the smallish chateau were situated, and that its very name referred to a site that was the ancient "centre" of France in a "val [vers] de Gallie" is, I think, nonsense, if only because such a history surely would have played a role in the subsequent mythological language of the palace. ${ }^{25}$

Though we cannot finally answer the question why Louis chose Versailles, there is no shortage of sources allowing us to interpret the symbolism and rhetoric of the constructions he built there. In doing so, we should realise that what remains of the 1660- and 1680-parts of the chateau and its park to a great extent really does reflect Louis's wishes. For he was passionate about architecture $^{26}$ - perhaps even more so than most Roman pontiffs - with, perhaps, the exception of his contemporary and, in a sense, rival, Pope Alexander VII, whose court architect, Bernini, Louis even tried to "steal."27

After having used his father's hunting-lodge during the years $1661-1668,{ }^{28}$ Louis decided to enlarge it - against the wishes of the new director-general of

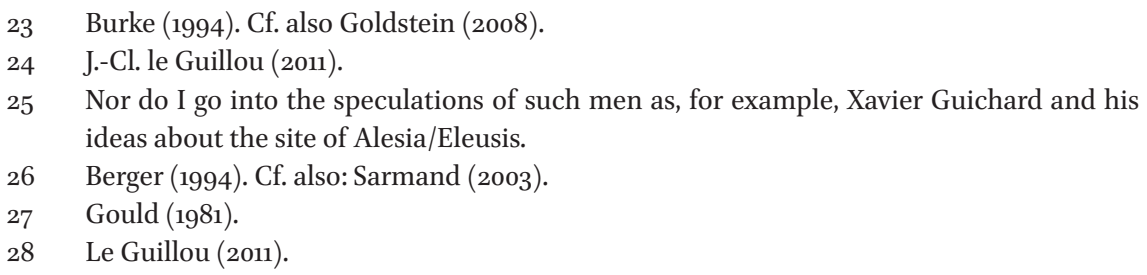


the realm's finances, Jean-Baptiste Colbert. ${ }^{29}$ During the following decades, thousands of farmers were requisitioned to work there; given the unhealthy site, many never left it - their dead corpses being carried away by the cartloads, as Madame de Sévigné tells us in a letter dated 12 October 1678. By 1685, some 36.0oo men were "employed" in the building, while de-commissioned soldiers from the French army - at this time not, as usually, engaged in one of Louis's many bloody and costly wars - were toiling away there as well.

During the first building-phase, the original chateau was "encapsulated" in a far bigger, symmetrical structure, basically consisting of a wing for the king and one for the queen - both containing seven rooms - separated by a courtyard, but linked by an elevated terrace. The interior, especially on the king's side, was heavily symbolic. As André Félibien, the historiographer royal, wrote in his Description sommaire du Chasteau de Versailles (Paris 1674, and later):

As the Sun is the devise of the King, the seven planets have been taken as the inspiration for the decoration of the seven rooms, in such a way that in each, one sees the actions of the heroes of Antiquity who are related to these planets and to the deeds of His Majesty.

Thus, the main reception room of the king's suite - placed right at the centre - was dedicated to Apollo, the Sun God himself, the ruler of the universe. Indeed, all over the palace, to start with the great wrought-iron entrance Gates, Apollo's emblem, the lyre, was in abundant evidence. In short, Versailles was a palace under the sign of the Sun.

Nor is it difficult to find some of the ideological-political roots of this choice. In September 1638, the French queen - at last pregnant with her first child, the much-longed for heir to the throne - had asked the Italian philosopher Tommaso Campanella (1568-1639) to cast her son's horoscope. Campanella had written extensively on the idea of a "Monarchia delle Nazioni," as well as about its "ideal" capital, the "Civitas Solis," the "City of the Sun" - the title of his 1623book of which a new version was published in Paris in, incidentally, 1638 . He foretold the queen that one day her boy would be the man in whom this "universal monarchy" would be personified. ${ }^{30}$

Campanella's tract was essentially a theological-political vindication of the various policies pursued by France's leading politicians - cardinals Richelieu and Mazarin foremost amongst them - to make France the leading state of Europe, and its king "by Divine Right" the arbiter of all the nations, foremost

29 Berger (1994) 33, 64, 72; Sarmand (2003) 326.

30 Grimm (1986). 
amongst them the obnoxious Dutch and, of course, the two Habsburg dynasties, those of Austria and, even more so, of nearby-Spain, though both his mother and his wife were Spanish princesses.

No wonder Louis, who, after Mazarin's death in 1661 felt he finally became his own master, wanted to create a palace worthy of this prophesy - though, I would argue, Campanella's detailed description of the Sun City's central temple certainly was not repeated in the architecture of the palace (see Figure 5.2 and 5.3). No wonder, either, that the King himself used to explain the symbols of the various rooms his visitors were allowed or, rather, gently forced to see and admire. He would refer to Ovid's "Metamorphoses" - a source for many of the mythological stories depicted in Versailles - or, if need be, to the Bible. If his visitor was a military or naval man, the King would draw his attention to the decoration of the rooms dedicated to Mars and Neptune, or, for that matter, point out that the last of the rooms, connecting the king's wing with that of the queen, bore the sign of Venus, the Goddess of Love. ${ }^{31}$ Thus, the progress through the palace's rooms took on something of a journey through cosmological time and space, in order to reach the universe's creative source. Not surprisingly, Louis's personal devise was Foecundis ignibus ardet - 'it [he] burns with fruitful fire'. To put it otherwise: Louis settled himself and, thereby, the monarchy. No longer did the French king, like his forebears, tour the realm, to show himself to, and, in a sense, to negotiate with his subjects. Like the Sun, he became the fixed centre of his kingdom, the source of all power ${ }^{32}$ - or so he wanted people to believe.

In comparison to real models, Louis wanted his new seat both to emulate and to supersede what his brother-in-law, Philip IV of Spain, had created in and around Madrid. ${ }^{33}$ In this palace, Louis told his courtiers in 1686: "Nous nous devons tout entier au public,"34 indicating that the king of France was always on show - like an idol. Indeed, he also wanted to show himself and his power to all those who never would actually meet him in person, though they might visit Versailles, since the palace was in many ways an open place where tourists - "avant la lettre" - were welcome, if properly accoutred. Moreover, he wanted to impress the world at large. Therefore, printed descriptions of the palace and its decorations were widely distributed, for example in extensive articles - sometimes amounting to veritable booklets - in such journals as the

$31 \quad$ See the various instances given of Louis's own role as a "guide" in Hautecoeur (1953), and Guillou (1963), both summarised by Sabatier (1999) 32 sqq.

32 Sabatier (1985) 307-08.

33 Sabatier (2014).

34 Bernier (1836) 220. 


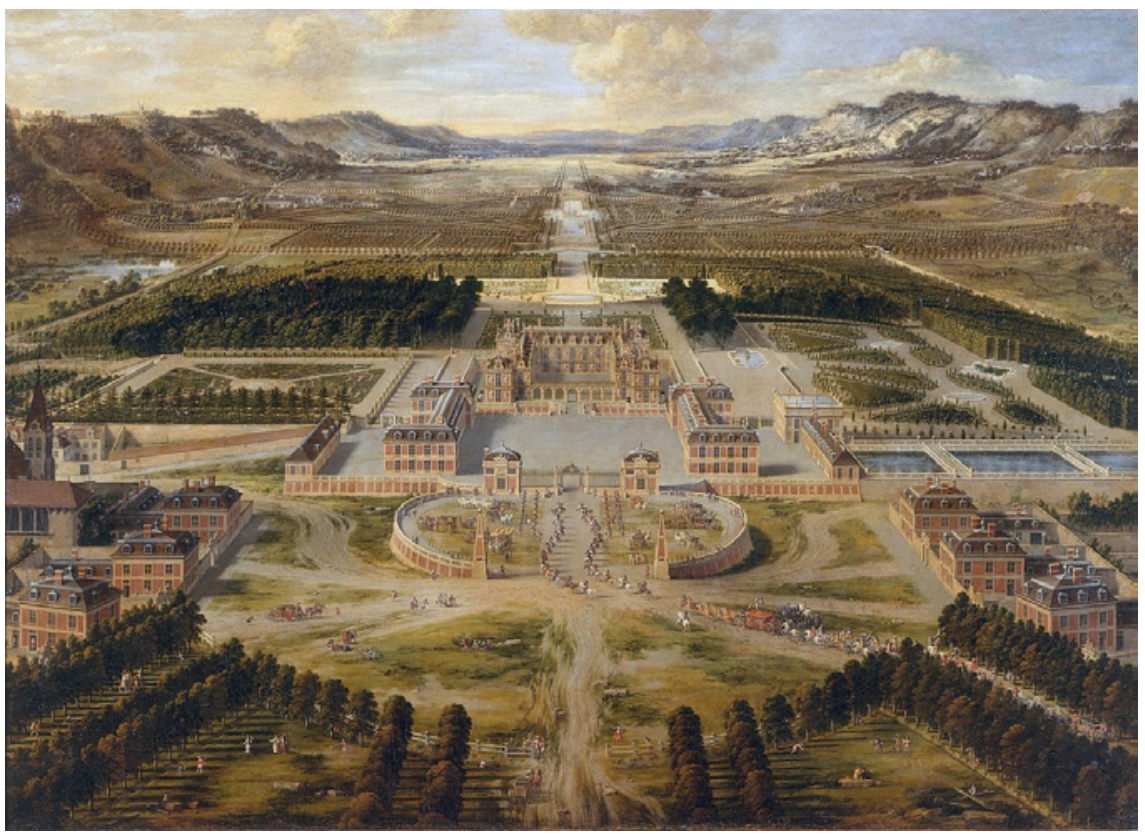

FIGURE 5.2 Versailles, during the first building campaign, ca 1670. Pierre Patel, ca. 1670. Credits: Wikimedia Commons, the free media repository [accessed online 28.02.2019, <https://nl.wikipedia.org/wiki/Bestand:Chateau_de_Versailles_1668_ Pierre_Patel.jpg $>$ ]

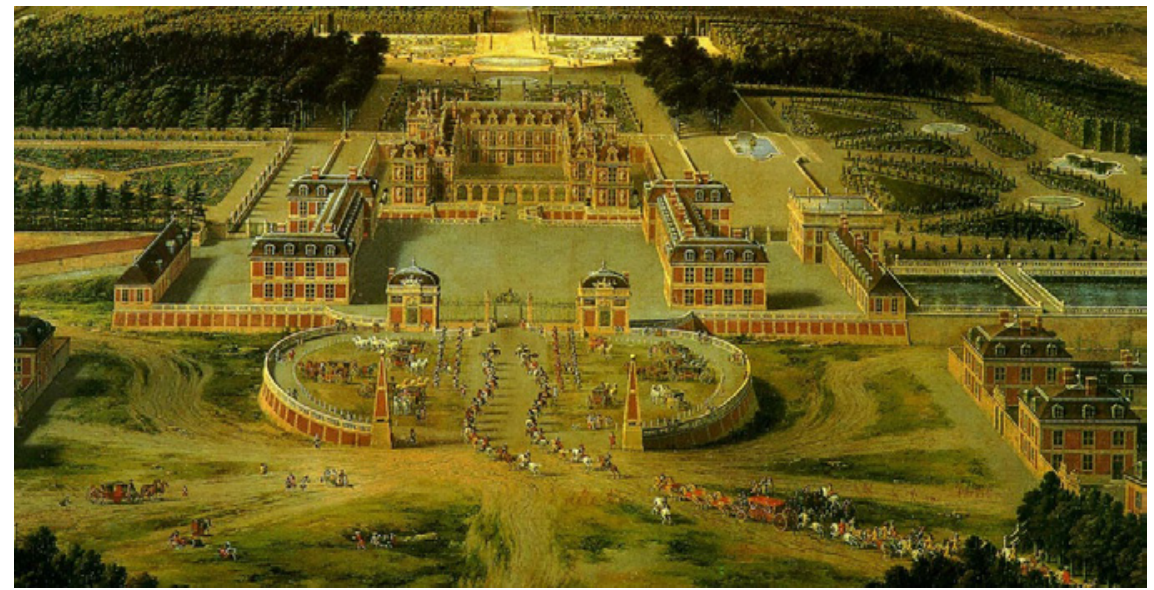

FIGURE 5.3 Versailles, after the last building campaign, ca 1720. Pierre-Denis Martin, ca. 1720. Musée national des châteaux de Versailles et de Trianon. Credits: Wikimedia Commons, the free media repository [accessed online 28.02.2019, <https:// en.wikipedia.org/wiki/History_of_the_Palace_of_Versailles\#/media/ File:Versailles_Pierre-Denis_Martin.jpg>] 
Mercure galant and, of course, the government-sponsored Gazette de France..$^{35}$ Also, over the decades, the "royal printing office," as well as other commercial publishers, brought out a number of often illustrated guide-books. Large, engraved representations of the chateau and its surroundings were printed, too, accompanied by a short description. All in all, from the years between ca. 1670 and 1715 , I count some 25 texts, including reprints that, of course, often were updated to document the many alterations the palace underwent.

For during the 168 os, the palace's disposition was greatly changed. On the first floor, the terrace linking the king's and the queen's wing was replaced with a magnificent gallery, lined with mirrors - think: light and Sun! - which, significantly, on the king's side one entered through the "Salon de la Guerre," and left again through the "Salon de la Paix" to gain the queen's side - an ideologically gendered sequence, one might say. However, in the "Gallerie des Glaces," the huge frescoes that adorned the walls and the ceilings no longer extolled a planet and its mythology, but Louis himself and his real, historical exploits on the (inter-)national scene, albeit in visual tales that, sometimes, distorted the actual state of affairs in the world. At the very centre, in a ceiling fresco glorifying the King, the various nations of Europe made subservient to him bow their knee - not to France, but to its apotheosed monarch, who is represented with the explication: "The King Governs by Himself." Indeed, by that time Louis had adopted a new motto: he now also felt Nec pluribus impar, which might be translated as '[he reigns] above all'. Maybe he remembered one of the sermons of his court preacher, J.-B. Bossuet, who had told his audience: "Vous voyez l'image de Dieu dans les rois," and, addressing the King himself while citing Scripture, had even said: "Vous êtes des dieux [...]," though yet warning his royal parishioner that he, too, would die like any mere mortal. ${ }^{36}$

Nevertheless, the king was, indeed, "idolised," with even the tiniest moments of his daily routine being used for the public display of his unique position. It was, also, part of Louis's much-discussed policy of binding France's nobles to his court and, indeed, his person. ${ }^{37}$ Much of the ritual and ceremony took place in the "Chambre du Roi," the King's bedroom and, therefore, in a sense the most exclusive room of the chateau. After the major alterations of the 1680 s, it now was situated right at the heart of the entire palace - but, more significantly, also on the central axis of the gardens and the town that slowly came to surround the "Dwelling of the Sun" like a planet's two halves. For

35 E.g. Le Mercure galant, December 1682, 6-13; December 1684, 1-84; April 1687, 14-56.

36 Oeuvres Complètes de Bossuet, $\mathrm{x}(1836) 385$.

37 How successful he - and, indeed, the set-up of Versailles - was, remains a matter of much debate. Cf., for example, W. Newton (2000). 
during the last decades of the century, Versailles reached its final form. By then, the complex had come to encompass not only the building itself, but the world around it. Palace, park, and city now were (re-)designed as an ensemble meant to resemble the world of which the King's state rooms were the centre. Admittedly, given the enormous extent of the ensemble, this is more visible on the many printed plans and the painted or engraved bird's-eye perspectives of the time than it was, or is, in actual reality.

One of the circle's halves, extending outward from the terrace in front of the Gallery of Mirrors, is taken up by the huge gardens - covering some 1,00o hectares - designed by André le Nôtre. Though they have been considerably altered - even during Louis's reign - originally, they meant to achieve a number of goals at the same time. The lay-out presented the park as a cosmic space ${ }^{38}$ of interlocking circles and squares, linked by radiating pathways, each half symmetrically flanking the central axis that, starting at the "Chambre du Roy," basically was formed by the 1.5 kilometre-long "grand canal." Everywhere such elements as, for example, four fountains representing the four seasons provided focal points. But the park also served as an open-air extension of the representational functions of the palace, with a dining-room, a ballroom, an audience chamber, et cetera, created by green walls - trained and clipped trees - and studded with statuary. No wonder, then, that the park was consistently used to impress foreign visitors: every diplomat who came to bow before the King not only was expected to inspect and dutifully admire the palace itself, but also to take the tour of the gardens - sometimes even accompanying Louis himself. ${ }^{39}$ Indeed, in his later years, the King sat down and actually wrote a "Manière de montrer les jardins de Versailles," indicating the exact route that should be taken. ${ }^{40}$

Of course, Louis wanted those who could only read about his magnificence to be exhaustively informed as well. Therefore, a number of authors took care to set out and explain every detail of the park's decoration in descriptions and guide-books. I count at least fifteen specifically such between 1670 and 1715 . Interestingly, they did not invite the audience to enjoy "nature" but, rather, to marvel at the way the King had managed to "embellir la nature, ou à la surpasser."41 Actually, the texts almost exclusively stress man-made objects, showing Louis not only as the person who had built "le plus superbe Palais du Monde," ${ }^{\text {"2 }}$ but, as Félibien tellingly put it, who also "par une espèce de

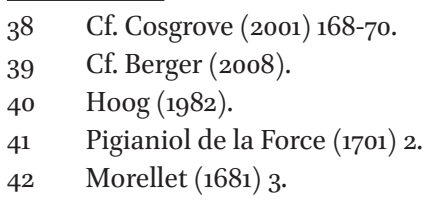


creation" had given the world this wonder. ${ }^{43}$ Thus, the King became almost Dieu ruling over a world that no longer was chaotic, but ordered according to his will - as he pretended to order France and as he would have liked to order Europe. ${ }^{44}$

For let us not forget that both palace and gardens were constantly watched - by the King's guards and, indeed, by the new police force. ${ }^{45}$ And of course they watched the "new" town of Versailles, too - for towns were, traditionally, hotbeds of the kind of unrest most feared by kings. Already in 1671, Louis, desiring to complete his vision of an ideal palace-cum-town, had decided to raze the old village and create a new city, by giving out building plots to people with the express obligation to actually construct their dwellings there. Until the end of the eighteenth century, all buildings had to be of the same height and colour, according to specifications expressly issued by the King himself, ${ }^{46}$ to ensure the intended view-lines towards and, of course, from the palace.

Linking the new town with the capital was the "Avenue de Paris." Starting at the palace gates and bordered there by the enormous stable blocks needed to house the royal coaches and horses, it was an unheard-of 90 meters wide and ran straight for about one-and-a-half kilometre before, beyond the palace's horizon, joining up with the old road to the capital.

To complement this urban lay-out, two other avenues were created, thus forming a trident intersecting the half of the circle given to the town. Soon, distinct town-quarters developed, one around the newly-built church of NotreDame de Versailles, for which Louis personally laid the first stone in 1684, and another around the church of, significantly, Saint-Louis, which was finally built in the 1730 . These quarters slowly filled with houses and shops. Also, two monasteries, a hospital and, last but not least, a tennis-court for the King and the court nobles were constructed to accommodate the various needs of the everincreasing number of people somehow serving the "economy" of the royal court and the central administration of the state. ${ }^{47}$ For as indicated above, in 1682 the King did transfer his government from Paris to Versailles. Consequently, the number of inhabitants swelled from a few hundred in the 1660 s to some 20,000 by the end of Louis's reign. 48

\footnotetext{
43 Félibien (1674) 340.

44 E.g. Mukerji (1997).

45 Le Nabour (1991).

46 See: Dauphin (2004) for a very short introduction. For a detailed survey of the town during the "Ancien Régime": Bottineau (1988), as well as: Breillat (1986), which also gives a number of plans to show the town's development.

47 Da Vinha (2009) passim.

48 Cf. Lepetit (1977).
} 
When in 1715 the realm's regent, Philippe of Orleans, decided to return both the court and the business of government to Paris, the population of Versailles dwindled to half its size, again. Yet, from 1722 onwards, it rapidly became populous and prosperous once more. During the reigns of Louis XV and Louis XVI, some grand office-buildings were erected to house the ministry of foreign affairs and of war, respectively. Meanwhile, the number of inhabitants rose to some 50,00o, making Versailles one of the larger towns of "Ancien Régime"France. Nevertheless, it was not in any sense a "normal" town, with its own civic institutions, rituals and ceremonies. Rather, it was the inflated appendage of the palace and its inmates, under the strict control of a royal official.

\section{Conclusion}

After Louis's death, further changes were made both in the palace and the gardens of Versailles - in the 1740s and 1750s, and again in the nineteenth century. Still, the "Dwelling of the Sun" as he had envisaged it has remained not only as the exemplar of a royal palace but, also, as the embodiment in stone of royal absolutism, a piece of petrified rhetoric if ever there was.

Rome, too, underwent changes. Yet, though from the 1870 os onwards the kingdom of Italy introduced its grand royal-bureaucratic buildings and, in the 1930s, the Fascist government tried to imprint it with its own specific brand of power architecture, the actual city-centre remains very much as the "Baroque popes" have left it in the late seventeenth century, with St Peter's Square and the basilica as its enduring symbol.

Comparing "Versailles" with "Rome," we now see the latter as the prime embodiment of a religious monarchy, or, even, autocracy, while the former stands for a secular one. However, the distinction between these two "realms" was far less clear-cut during the "Ancien Régime" than scholars sometimes assume. The popes, though ecclesiastical princes first and foremost - which meant they could and did use all references to religious and, indeed, transcendental power available - very much represented themselves with all the trappings of a temporal monarch. On the other hand, despite the largely secular base of their power, the kings of France never ceased to present themselves in a religious, transcendental context as well, employing both pagan mythology and Christian iconology. Actually, perhaps no one did so more comprehensively than the fourteenth Louis. His last great project, putting the finishing touch to Versailles, was the monumental palace chapel: modelled, significantly, on the 
thirteenth-century Sainte-Chapelle in Paris, the "national" shrine of France, and filled with symbols of Divine Right-monarchy. ${ }^{49}$

Nor were the two towns "normal" as were most other cities in Europe, in the sense that the population somehow could voice its concerns vis-à-vis the monarch who also lived there. In Rome, the papacy had succeeded in abolishing the erstwhile independence of the city council and its three "conservatori" on the Capitol. In Versailles, the power of the chosen syndic was, by and large, meaningless, too. In these towns, the ruler reigned supreme.

Last but not least, one might argue that "Baroque" Rome was an answer to at least two challenges presented to the papacy of the late sixteenth and the seventeenth century: the one by a Humanism seen as a return to paganism, and the other by the Reformation against Christianity and the universal role of Rome in it as understood by the popes. ${ }^{50}$ Versailles also posed an answer to a challenge - the challenge of a polity in which both the urban elites and the aristocracy had tried to reduce royal power. ${ }^{51}$ Both the popes and the French kings sought to uphold and even strengthen their position against the forces that, they felt, were undermining it. To make their pretences abundantly clear, as monarchs "by Divine Right" - the one through divinely-sanctioned birth, the other through divinely-inspired election - the men who ruled in Versailles and Rome fully exploited all aspects of visual propaganda. In doing so, they also elevated the political rhetoric of capitals to a new height.

\section{Bibliography}

Ackermann, J., "Rome in the Renaissance," in P. Ramsey (ed.), Rome in the Renaissance, Medieval and Early Renaissance Studies 8 (Binghamton, 1982).

Bauval. R., The Vatican Heresy. Bernini and the Building of the Hermetic Temple of the Sun (Rochester, 2014).

Berger, R., and T. Hedin, Diplomatic Tours in the Gardens of Versailles under Louis XIV (Philadelphia, 2008).

Berger, R., A Royal Passion. Louis XIV as Patron of Architecture (Cambridge, Mass., 1994). Berger, R., Versailles: the Chateau of Louis XIV (University Park, 1985).

Bernier, A., (ed.), [Marquis de Sourches] Mémoires secrets et inédits de la cour de France, II (Paris, 1836).

Bird, J., Centrality and Cities (London, 1977, repr. 2007).

49 Edmunds (2002). Cf. also Rietbergen (2016).

$5^{0} \quad$ Labrot (1987).

$51 \quad$ Sabatier (1990) 307 sqq. 
Bluche, F., Louis XIV (Paris, 1999).

Bottineau, Y., "Essais sur le Versailles de Louis XIV. I: La distribution du château et le plan du domaine et de la ville," in Gazette des Beaux-Arts 112 (1988), 77-98.

Breillat, P., Ville nouvelle, capitale modèle: Versailles (Versailles, 1986).

Burke, P., The Fabrication of Louis XIV (New Haven, 1994).

Ciucci, G., La Piazza del Popolo (Rome, 1974).

Cosgrove, D., Apollo's Eye. A Cartographic Genealogy of the Earth in the Western Imagination (Baltimore, 2001).

Dauphin, N., "Versailles, le château et la ville. Deux patrimoines distincts, duex mémoires antagonistes à l'époque contemporaine," in Histoire urbaine 9 (2004), 79-96.

Delph, R., "Renovatio, Reformatio, and Humanist Ambition in Rome," in R. Delph, M. Fontaine, and J.J. Martin (eds.), Heresy, Culture and Religion in Early Modern Italy: Contexts and Contestations (Kirksville, 2006), 73-92.

Duindam, J., Vienna and Versailles. The Courts of Europe's Dynastic Rivals, 1550-1780 (Cambridge, Eng., 2003).

Edmunds, M., Piety and Politics. Imaging Divine Kingship in Louis XIV's Chapel at Versailles (Newark, 2002).

Eliade, M., The Sacred and the Profane (New York, 1961).

Félibien, A., Description sommaire du Chasteau de Versailles (Paris, 1674).

Frommel, C., "Papal Policy; the Planning of Rome during the Renaissance," inJournal of Interdisciplinary History 17 (1986), 39-65.

Goldstein, C., Vaux and Versailles. The Appropriations, Erasures and Accidents that Made Modern France (Philadelphia, 2008).

Gould, C., Bernini in France (Princeton, 1981).

Grotenhuis, E. ten,Japanese Mandalas: Representations of Sacred Geography (Honolulu, 1999).

Grimm, J., "Campanella in France," in J. Serroy (ed.) La France et l'Italie au temps de Mazarin (Grenoble, 1986), 79-86.

Guillou, E., Versailles: le palais du Soleil (Paris, 1963).

Guillou, J-C. le, Versailles avant Versailles Au temps de Louis XIII (Paris, 2011).

Hautecoeur, L., Louis XIV, Roi-Soleil (Paris, 1953).

Hoog, S., (ed.), Louis XIV: manière de montrer les jardins de Versailles (Paris, 1982).

Kitao, T., Circle and Oval in the Square of Saint Peter's: Bernini's Art of Planning (New York, 1974).

Labrot, G., L'image de Rome. Une arme pour la Contre-Réforme (1534-1667) (Seyssel, 1987).

Le Nabour, E., La Reynie: le policier de Louis XIV (Paris, 1991).

Lepetit, B., "Demographie d'une ville en gestation: Versailles sous Louis XIV," in Demographie paroissiale. Annales de Demographie Historique. Societé de Demographie Historique 11 (1977), 49-83. 
Mapier, D., "Bernini's Anthropology: A 'Key' to the Piazza San Pietro," in Anthropology and Aesthetics 16 (1988), 17-32.

McDannell, C., and B. Lang, Heaven: A History (New Haven, 2001).

Morellet, L., Explication historique de ce qu'll y a de plus remarquable dans la masion royale de Versailles (Paris, 1681).

Miedema, N., Rompilgerführer im Spätmittelater und früher Neuzeit (Tübingen, 2003).

Miedema, N., Die “Mirabilia Romae.” Untersuchungen zu ihrer Überlieferung (Tübingen, 1996).

Minkenberg, M., (ed.), Power and Architecture: the Construction of Capitals and the Politics of Space (New York, 2014).

Mukerji, C., Territorial Ambitions and the Gardens of Versailles (Cambridge, Eng., 1997).

Müller, W., Die heilige Stadt: Roma quadrata, himmlisches Jerusalem und die Mythe vom Weltnabel (Stuttgart, 1961).

Narayanan, Y., Religion, Heritage and the Sustainable city. Hindusm and Urbanization in Jaipur (London, 2015).

Newton, W., L'espace du roi: la cour de France au chateau de Versailles, 1682-1789 (Paris, 2000).

Patricios, N., "Concepts of Space in Urban Design, Architecture and Art," in Leonardo 6 (1973), 311-318.

Perouse de Montclos, J-M., Versailles (Paris, 1991, repr. 2001).

Pigianiol de la Force, J-A., Nouvelle description des chasteaux et parcs de Versailles (Paris, 1701).

Quinlan-McGrath, M., “The Foundation Horoscope(s) for St. Peter's Basilica, Rome, 1506: Choosing a Time, Changing the Storia," in Isis 92 (2001), 716-741.

Rietbergen, P., "Sacralizing the Palace, Sacralizing the King. Sanctuaries and/in Royal Residences in Medieval Europe," in M. Verhoeven, L. Bosman, and H. van Asperen (eds.), Monuments and Memory. Christian Cult Buildings and Constructions of the Past (Turnhout, 2016).

Rietbergen, P., Clio's Stiefzusters. Verledenverbeeldingen voorbij de wetenschap (Nijmegen, 2015).

Rietbergen, P., Rome and the World, the World in Rome (Dordrecht, 2013).

Rietbergen, P., Power and Religion in Baroque Rome. Barberini Cultural Policies (Leiden, 2006).

Rietbergen, P., Rome Gelezen. De retoriek van de Eeuwige Stad (Nijmegen, 2003).

Rietbergen, P., "Pausen, prelaten, bureaucraten. Apecten van de geschiedenis van het pausschap en de pauselijke staat in de 17 e eeuw," PhD Diss., (Catholic University Nijmegen, 1983a).

Rietbergen, P., “A Vision Come True. Pope Alexander viI (1655-1667), Gianlorenzo Bernini and the Colonnades of St. Peter's," in Mededelingen van het Nederlands Instituut te Rome, XLVI, Nova Series 11 (1983b). 
Sabatier, G., and M. Torrione (eds.), Louis XIV espagnol? Madrid et Versailles, images et modèles (Versailles, 2014).

Sabatier, G., Versailles, ou la Figure du Roi (Paris, 1999).

Sabatier, G., "Versailles, un imaginaire politique," in Publications de l'Ecole francaise de Rome 82 (1985), 295-324.

San Juan, R., Rome: A City out of Print (Minneapolis, 2001).

Sarmand, T., Les Demeures du Soleil. Louis XIV, Louvois et la surintendance des batiments du roi (Seyssel, 2003).

Sinisi, D., and C. Genovese (eds.), Pro Ornatu et Publica Utilitate. L'attività della Congregazione cardinalizia "super viis, pontibus et fontibus" nella Roma di fine '50o (Rome, 2010).

Smith, B.L., and H. Baker Reynolds (eds.), The City as a Sacred Center. Essays on Six Asian Contexts (Leiden, 1987).

Torres, P., Les Secrets de Versailles (Paris, 2015).

Vinha, M., de, Le Versailles de Louis XIV (Paris, 2009).

Westfall, C., In this Most Perfect Paradise: Alberti, Nicholas $V$ and the Invention of Conscious Urban Planning in Rome, 1447-55 (Philadelphia, 1974).

Zabriskie, B., "Jung and Pauli," in Journal of Analytical Psychology 40 (1995), 531-553.

Zhu, J., Chinese Spatial Strategies: Imperial Beijing, 1420-1911 (London, 2004). 